\title{
Author response: bone health in men: still suffer the gender gap
}

\author{
W. D. Leslie ${ }^{1}$ (1) - L. M. Lix ${ }^{2} \cdot$ N. Binkley ${ }^{3}$
}

Received: 7 February 2021 / Accepted: 19 February 2021 / Published online: 4 March 2021

(C) International Osteoporosis Foundation and National Osteoporosis Foundation 2021

Dear Editor,

We wholeheartedly support these comments from Sirufo et al. [1] regarding the osteoporosis care chiasm that exists among men, which dwarfs the widely publicized care gap in women [2]. Although men develop osteoporosis and related fractures less frequently than women, men still contribute substantially to the osteoporotic fracture burden at the population level-more than one-quarter of all hip fractures occur in men and age-specific hip fracture rates are approximately half those of women [3]. Moreover, men more commonly experience adverse outcomes following fracture including greater death and institutionalization [4, 5]. Although not the focus of our study, the authors correctly highlight that only $13 \%$ of the individuals over age 65 undergoing baseline DXA testing were men, which is significantly smaller than their relative contribution to fractures in the population [6]. This low testing rate among men reflects current practice patterns and should not be construed as in any way optimal or supported by the authors. Guidelines, which still frequently target postmenopausal women, need to acknowledge and address this serious shortcoming [7, 8].

W. D. Leslie

bleslie@sbgh.mb.ca

L. M. Lix

lisa.lix@umanitoba.ca

N. Binkley

nbinkley@wisc.edu

1 Department of Medicine, University of Manitoba, 409 Tache Avenue, Winnipeg, Manitoba R2H 2A6, Canada

2 University of Manitoba, Winnipeg, MB, Canada

3 University of Wisconsin, Madison, WI, USA

\section{References}

1. Sirufo MM, Ginaldi L, De Martinis M (2021) Bone health in men: still suffer the gender Gap. OsteoporosInt. (in press)

2. Khosla S, Cauley JA, Compston J, Kiel DP, Rosen C, Saag KG, Shane E (2017) Addressing the crisis in the treatment of osteoporosis: a path forward. J Bone Miner Res 32(3):424-430

3. Leslie WD, O'Donnell S, Jean S, Lagace C, Walsh P, Bancej C et al (2009) Trends in hip fracture rates in Canada. JAMA. 302(8):883-889

4. Morin S, Lix LM, Azimaee M, Metge C, Caetano P, Leslie WD (2011) Mortality rates after incident non-traumatic fractures in older men and women. Osteoporos Int 22(9):2439-2448

5. Morin S, Lix LM, Azimaee M, Metge C, Majumdar SR, Leslie WD (2012) Institutionalization following incident non-traumatic fractures in community-dwelling men and women. Osteoporos Int 23(9): 2381-2386

6. Leslie WD, Lix LM, Binkley N (2020) Comparison of screening tools for optimizing fracture prevention in Canada. Arch Osteoporos 15(1):170

7. Porcelli T, Maffezzoni F, Pezzaioli LC, Delbarba A, Cappelli C, Ferlin A (2020) Management of endocrine disease: male osteoporosis: diagnosis and management. Should the treatment and target be the same as for female osteoporosis? Eur J Endocrinol

8. Colon-Emeric CS, Pieper CF, Van Houtven CH, Grubber JM, Lyles $\mathrm{KW}$, Lafleur J et al (2018) Limited osteoporosis screening effectiveness due to low treatment rates in a national sample of older men. Mayo Clin Proc 93(12):1749-1759

Publisher's note Springer Nature remains neutral with regard to jurisdictional claims in published maps and institutional affiliations. 